\title{
Strengthening Capacity through Expansion of Community Participation in Mangrove Ecotourism Management in Pamurbaya
}

\author{
Tjitjik Rahaju*, Agus Suryono, Mardiyono, Siti Rochmah \\ ${ }^{a}$ Universitas Negeri Surabaya, Surabaya, East Java, Indonesia \\ Universitas Brawijaya
}

\section{ARTICLE INFORMATION}

\section{ABSTRACT}

\section{Article history:}

Data submission : 10 October 2019

$1^{\text {st }}$ revision: 10 November 2020

Accepted: 16 December 2020

Available online: 30 December 2020

Keywords: Strengthening Capacity; Participation; Mangrove Ecotourism
The movement of the public sector in development has become important in relation to the governance agenda (Pomerantz in Bevir,2011;164). Development failures in many developing countries are due to the presence of insignificant community participation in poverty alleviation (Grindle,2004;526). Surabaya is an example of a city that is trying to continue to empower its people through various activities under Dinas Pertanian dan Ketahanan Pangan. The potential of coastal areas that are rich in mangroves in Surabaya along the East Coast of Surabaya (Pamurbaya) is the choice to empower the community with mangrove ecotourism designn. Theoretically the phenomenon of empowerment in the view of researchers is interesting to study. Considering even though there have been many empowerment programs implemented in Pamurbaya. The existing program has not been able to fully complete community capacity development. Active community participation was also still limited and the achievement of prosperity that needs to be improved.

2020 FIA UB. All rights reserved..

\section{Introduction}

The development of the coastal area as a mangrove ecotourism area has become a concept that has been staging in recent years. The development of the coastal area as a mangrove ecotourism area has become a concept that has been staging in recent years. A better understanding of mangrove management is needed. In this context the consideration of various stakeholders is necessary so that the potential of mangroves is productive and can be utilized optimally (Hug, 2016). Likewise, Surabaya East Coast which was developed as a mangrove ecotourism area to become an ecotourism area is the right choice (Hakim, Siswanto, Nakagoshi, 2017). Also, in relation to the productivity of community-driven mangrove areas (Jeannyla, et al., 2018). Initiation of Surabaya city government in this region also gives important meaning to increase the added value and competitiveness of the city. As the concept called Cullen and Chusman (2000).

Through ecotourism, the economic movement of the community was very possible to develop. Various businesses supporting ecotourism were held, and the community as the main actors. Optimizing the potential of high-value wealth and natural beauty by the community has great significance for the people around ecotourism. So that its development carries a big role in not only economic aspects but also social and environmental aspects.

This study becomes more interesting if it is related to the context of providing capacity building for local communities. In the researchers' initial understanding, community management of mangrove areas reflects the pattern of full community participation. This will strengthen its capacity to plan, implement and evaluate forms of management that can be developed. Mangrove cultivation by the surrounding community, has economic value as well as being meaningful in environmental preservation efforts. While the pioneering ecotourism Pamurbaya mangrove, can provide education to the entire community. Through a package of activities promoting the benefits of mangroves, nurseries, planting mangrove seeds, visitors are invited to enjoy tours with the concept of education. However, it seems, the limited ability of the surrounding community is barrier. So, the diversification of the business carried out by the surrounding community so far has not produced optimal results. 


\section{Theory}

Regarding capabilities, in Clark's (2019) understanding, going beyond this provides conceptual work agreements that are relevant for development. Especially discussing the current concept of development when maintenance (SDGs). Recognize that the importance of participatory processes is to achieve many of their targets effectively, accountably, in ways that are inclusive (United Nations, 2018). But it is also weak socially, poor and helpless. This concept reflects the new paradigm of development, which is "people centered, participatory, empowering, and sustainable" (Chambers, 1997).

This condition in the understanding of Sen (1999) needs to be strengthened with the capability assessment and gives space for broader participation in poor communities. Referring to UNDP (2004) this is interpreted as a process that must be able to benefit all individuals fairly, and participation as the core.

The community empowerment approach is a step taht must be taken in achieving the nation's goals (Wrihatnolo and Nugroho, 2007). Frediani, Clark, Biggeri (2019) developing human development and enhancing capabilities is done by emphasizing the role of empowerment and participatory methods that can be applied.

\section{Research Method}

The research also intends to explore, unravel, and reconstruct the role of participation and enhancing capabilities in the context of community empowerment in the Pamurbaya mangrove area. Through tracing interview information, it is known that from the beginning the community was involved. In this context, participation is found in the form of community involvement that is associated with the attention and concern of mangrove ecotourism.

The study was conducted in the Pamurbaya Mangrove ecotourism area in two places namely Wonorejo and Gununganyar, Surabaya City, East Java Province, Indonesia. This location was chosen because of the management of tourism by the community as an initiation of capacity building for local communities in this area. Research data obtained using interviews, and observation and documentation study.

\section{Results}

The research also intends to explore, unravel, and reconstruct the role of participation and enhancing capabilities in the context of community empowerment in the Pamurbaya mangrove area. Through tracing interview information, it is known that from the beginning the community was involved. Referring to Frediani, Clark, Biggeri (2019) in this context, participation is found in the form of community involvement that is associated with the attention and concern of mangrove ecotourism.

\subsection{Participation and Welfare Improvement}

In understanding the communities around Pamurbaya the sustainability of the mangrove ecosystem continues to decrease. Though mangrove ecosystems are the main capital for the development of ecotourism which was introduced in Pamurbaya. Conditions of participation such as this occurred in the early days before the operation of mangrove tourism. Where the erosion of mangroves due to logging mangroves for community fuel. But this time it is not found anymore, because the community has switched to gas stoves. Based on these findings, it can be stated that participation is motivated by his desire to be involved in problem solving.

Where problems arise and are real around them and can be sure to threaten their lives. In the view of Creighton (2005) mentioned as an opportunity for individuals to take part in making decisions concerning the environment that affects them. According to Soetomo (2010:437) describing community participation in the process of identifying problems and potential that exists in the community, selection and decision making about alternative solutions to deal with the problem, implementing efforts to overcome problems, and community involvement in the process of evaluating changes that occur. Or according to Ferdiani in Frediani, Clark, Biggeri (2019) mentions the dynamics of internal factors that exist in society that encourage them to get involved. In addition there are also external influences in community involvement. The research findings unearthed through interviews and observations in the field, also showed that another problem that arose around the Pamurbaya mangrove area was the change.

The findings of the research show that the decreasing amount of mangrove lanf in the Pamurbaya area each year is due to the change in the function of the mangrove forest into housing and settlement. Responding to these conditions, the community feels anxiety because the productive land that has been a source of their livelihood is increasingly diminishing. Difficulties faced are related to the loss of pond land, while other skills are not widely owned by local communities. Considering all this time, the surrounding community depends a lot on their economic life from the marine life and potential of the surrounding mangroves. This threat is one of the reasons that drives the community to be involved in mangrove conservation activities. In the understanding of the community if this is left alone it will threaten their economic life. Because in the end it will have an impact on their welfare for the future.

\subsection{Participation and adaptive options}

The findings of research on empowerment conducted in the Pamurbaya Mangrove Area indicate the seriousness of the Surabaya City Government. Through related agencies to continue to always strive for empowerment programs carried out through various training. Until now the training continues. This shows that there are actually many choices that people can make to get involved and participate in many activities. Although this activity is more driven by the city government of Surabaya through related agencies. However, the findings show that not all of these options are able to provide space for the realization of full community participation as referred to Sen (1999), Chambers (1997), Creighton (2005) and Clark, Biggeri and Frediani (2019). The research findings show that examples of unpreparedness interpret community needs. Many trainings have been designed to provide understanding, open up insights and add skills. 
However, when the training process is completed, not many continue their abilities and skills in the form of independent businesses. Through further interviews, information was obtained that the possibility of lack of success in terms of business sustainability was due to the absence of an assessment of the types of needs that were explored from the aspirations of the community. Thus, this also means that the participatory process, positions the government not as a model that must be heard and followed. The findings that show empowerment in the Pamurbaya Mangrove Area shows teh existence of the community in various forms.

This is as mentioned Dusseldorp (1981) in Anwar (2007) who said community involvement can be done with 2 techniques namely community participation and organization. Or what is called Dusseldorp as a form of individual or group participation. In essence, mobilizing community participation can mobilize community resources to take part in the decision-making process. Besides utilizing the results achieved from community activities. Participation is shown by the community's involvement in the management of mangrove tourism by the people in Wonorejo and Gununganyar Pamurbaya. Through local institutions that are formed, the community is organized as part of the manager. This is mainly in the form of boat tours. In various economic activities supporting the Mangrove Wonorejo Ecotourism and Wisata Anyat Gunung Anyar. Through the organization of mangrove tourism, the community component is actively involved in various planned activities. It's just that active participation has not been seen much. The people who are actively involved until now are those who since the beginning of the opening of the tour are also leading the formation of mangrove tourism. While the supporting economic activities also have not experienced much change both from the number involved and the quality of involvement.

\section{Conclusion}

Strengthening the capacity of communities around Pamurbaya occurs through the process of managing mangrove ecotourismm. Community participation existed before the area was designated as ecotourismm. The idea of the emergence of the concept of ecotourism was also purely from the communityty. Increasingly visible in his involvement as a workforce in several fields in mangrove ecotourismm. However, the amount of community involvement tends not to develop. Participation was seen when the Department of Food Security and Agriculture made various training programs. But more in the form of physical presence. So that is interpreted only limited to when training is conductedd. Furthermore, the assistance and formation of group businesses only occur in a few business groups.

This research provides suggestions for strengthening community capacity to be expanded. Not only as an ecotourism manager, which turns out to be only limited to one type of business that is fully controlled by the community, namely tourist boat rental. But it needs to be expanded in the form of managing another field. The meaning of participation which is still limited to physical presence is expanded by providing training that is more in line with community needs. So that people are happy and enthusiastic to continue it as a productive economic endeavoror. Needs assessment needs to be done so that at the level of ideas, the idea of activities will purely emerge from the community. So that in the future the training design really matches the needs of the surrounding community.

\section{References}

Anwar. (2007). Manajemen Pemberdayaan Perempuan. Bandung: Alfabeta.

Bevir. (2011). The Sage Handbook of Governance. New Delhi: SAGE Publication Pvt. Ltd.

Chambers, R. (1997). Whose Reality Counts? Putting the First Last. London: Intermediate Technology.

Clark, D.A, Biggeri, M and Frediani, A. (2019). The Capability Approach, Empowerment and Participation: Concepts, Methods and Applications. United Kingdom: Palgrave Macmillan.

Creighton, J.L. (2005). The Public Participation Handbook: Making Better Decisions Through Citizen Involvement. San Fransisco: Jossey Bass A Wiley Imprint.

Cullen, R.B and Chusman, D.P.(2000). Transitions to Competitive Government. State University of New York Press.

Grindle, M.S. (2004). Good Enough Governance Poverty Reduction and Reform in Developing Countries. Governance: An International Journal of Policy, Administration, and Institutions. 17 (4): $528-48$

Hakim, S, Nakagoshi, N. (2017). Mangrove Conservation in East Java: The Ecotourism Development Perspectives in The Journal of Tropical Life Science.Available online 7( 3). 277 -285 . Available at doi: $10.11594 /$ jtls.07.03.14

Hug, J. (2016). Mapping discourses using $Q$ methodology in Matang Mangrove Forest, Malaysia at Journal of Environemtal Management xxx (2016) 1-10.

Jeannyla, B.S., Sulistyarso, H. (2018). Development of Mangrove Ecotourism Wonorejo Surabaya Based on Productive Landscape and Community Participation in International Journal of Scientific and Research Publications. Volume 8 (7):383389.

Neuman, W.L. (2015). Metodologi Penelitian Sosial: Pendekatan Kualitatif dan Kuantitatif. Edisi 7 Jakarta: Indeks Permata Puri Media.

Sen, A. K. (1999). Development as Freedom. Oxford, UK: Oxford University Press.

Soetomo. (2010). Strategi-strategi Pembangunan Masyarakat.Yogyakarta: Pustaka Pelajar.

UNDP. (2004). Human Development Report 2004: Cultural Liberty in Today's Diverse World. New York: Hoechstetter Printing Co. 